American Journal of Agricultural and Biological Sciences 6 (1): 84-91, 2011

ISSN 1557-4989

(C) 2010 Science Publications

\title{
Boric Acid Toxicity Trials on the Wood Borer Heterobostrychus aequalis Waterhouse (Coleoptera: Bostrychidae)
}

\author{
${ }^{1}$ Daljit Karam Singh, ${ }^{1}$ Faizah Abood, ${ }^{1,2}$ Hazandy Abdul-Hamid, \\ ${ }^{1}$ Zaidon Ashaari and ${ }^{1,2}$ Arifin Abdu \\ ${ }^{1}$ Department of Forest Management, Faculty of Forestry, \\ ${ }^{2}$ Laboratory of Sustainable Bioresource Management, \\ Institute of Tropical Forestry and Forest Products, \\ University Putra Malaysia, 43400 UPM Serdang, Selangor, Malaysia
}

\begin{abstract}
Problem statement: The Heterobostrychus aequalis Waterhouse was a serious pest lumber of timber heveawood. The $H$. aequalis infest and tunnel along the wood grain, depositing eggs, which concomitantly turn into larvae and reduces the wood starch to a soft powder. The objectives of the study were to establish a suitable method for preservative trials on the wood borer and access the toxicity levels of boric acid for controlling the $H$. aequalis infestation. Approach: The voracious $H$. aequalis was collected from infested heveawood, mated and cultured on cassava. The adult beetles were exposed to boric acid treated cassava blocks as pilot trials. The boric acid concentration used was $1-5 \%$ including a control. Each treatment consists of five replicates. The voracious of $H$. aequalis generation was cultured for obtaining its freshly new emerged adult by exposing a number of $H$. aequalis directly from infested heveawood into artificial diet block and cassava. The mortality, weight loss of the test blocks, frass discharge duration and numbers of holes caused by $H$. aequalis were observed. Results: The results showed that the $H$. aequalis infested tended to penetrate the film after wrapping the heveawood with a layer of transparent cling film for $24 \mathrm{~h}$ experiment. The H. aequalis larvae stock cultured collected from infested heveawood exhibited differences in colour, activeness and aggression among males and females. The suitable test block size used was $(2.0 \times 5.0 \times 1.5) \mathrm{cm}^{3}$. The freshly emerged voracious of $H$. aequalis adults was more suitable than the larvae for boric acid toxicity trials. The $2 \%$ concentration was sufficiently killed the $4 \%$ boric acid treated test blocks. There was no hole observed on $5 \%$ boric acid treated test block and hence these concentrations were not infested by $H$. aequalis due to absence of frass in exposed blocks. Conclusion/Recommendations: There are noticeable physical and behavioural differences between voracious of $H$. aequalis collected from infested heveawood. The freshly emerged of $H$. aequalis adults were found suitable than the larvae as an indicator for determining the boric acid toxicity trials. The $5 \%$ of boric acid concentration was sufficient to control the infection of $H$. aequalis on heveawood. Further studies focusing on interaction between larvae, adults and population growth of $H$. aequalis with different hosts need to be carried out towards clarifying the predisposing factors that induce the infestation processes.
\end{abstract}

Key words: Boric acid concentration, cassava block, heveawood, H. aequalis, toxicity trials

\section{INTRODUCTION}

Malaysia, undeniable is still one of the richest country with biodiversity of flora and fauna (Akbar et al., 2010; Leng et al., 2009; Saga et al., 2010; Satrio et al., 2009). It's also a home for various species of insects such as Heterobostrychus aequalis Waterhouse. The $H$. aequalis also known as false powderpost beetles or lesser auger beetle a serious pest of lumber especially heveawood. The adults as well as the larvae infest and bore on dried or seasoned wood and cause excessive damages to the wood structure (Creffield, 1991; Ivie, 2002; Peters et al., 2002). Previous studies found the distribution of $H$. aequalis in Andaman and Mariana Island, Malaysia, Phillipines, Sri Lanka Papua New Guinea and Cuba to name a few (Woodruff, 1967). Wong et al. (2005) and Akhter (2005) examined that heveawood have low durability and hence prominent to fungi attack and insect infestation due to high composition of starch. Hevea brasiliensis wood or

Corresponding Author: Arifin Abdu, Department of Forest Management, Faculty of Forestry, University Putra Malaysia, 43400 UPM Serdang, Selangor, Malaysia Tel: +603-89467177 Fax: +603-89432514 
normally known as heveawood is one of Malaysia biggest commodity products in particular furniture both for local and international. Lawrence and Britton (1991) studied that $H$. aequalis, infest, bore and tunnels along the wood grain, depositing eggs, which then emerges to larvae and reducing the wood starch to a fine, soft powder, earning them the name powderpost beetles (Peters et al., 2002).

Anatomically, the body length of $H$. aequalis is about 6-13 $\mathrm{mm}$ with the apical declining of elytra bituberculate on each side while the pronotum is lobed with teeth on the anterior border of pronotum broadly separated (Ho and Hashim, 1993). In addition, Woodruff (1967) described that $H$. aequalis has a broad tooth-like projection on its anterior of their sides. Furthermore, its sides are strongly deflexed on apical half with the projection of the posterior angles. The $H$. aequalis apical declivity of elytra arcuately deflexed. In order to differentiate the male and female of $H$. aequalis, the male has inner two stout tubercles pointing obliquely upwards. On the other hand, female $H$. aequalis has smaller pronotum, teeth on anterior apical border of pronotum shorter and the apical declivity of elytra without marginal tubercles (Ho and Hashim, 1993).

In general, pest control technician must identify the insects by examining the wood itself and by using the existence of emergence holes because larvae and adults of wood infesting beetles are hardly seen when damage occurred. Creffield (1996) found that for some wood boring beetles such as the longhorn beetles, only the insect larvae tunnel within the wood while all stages including larvae and adults of beetles such as pinhole borers tunnels in the wood. However, the insects which in turn decompose the woods could enhance the recycling nutrients and preventing the forest floor from being littered dead wood (Peters et al., 2002). Furthermore, the insect usually do not attack healthy trees and do not infect timbers after they have been milled.

Bostrychidae attack individual pieces of trim or flooring and rarely cause significant damage in framing lumber. Holscher and Wintersteen (1998) found that Dinoderus minutus is common in bamboo and rarely attack and infest seasoned wood. As for $H$. aequalis, the female bores into the wood and deposit its eggs in the tunnels that their made (Ho and Hashim, 1993). De Angelis (1995) examined that the female $H$. aequalis wills first "taste" the wood to determine whether it contains enough starch to nourish its offspring. Archer and Lebow (2007) stated that by coating the wood surface with paraffin wax, varnish shellac, or paint, it helps to prevent "tasting" and thus eggs will not be laid.
However, to our knowledge, there is a lack of information and studies for developing a standard method for preservative trials of wood borer of $H$. aequalis. Moreover, many wood preservation studies and methods only focus on how to eliminate $100 \%$ insect infestation on it rather than accurate studies on how to avoid pest attack by using a correct and standardize level of preservative. Therefore, the objective of this study is to project and establish a correct and suitable test method to study the behaviour or biology of $H$. aequalis together with the correct percentage of wood preservative concentration need to be used to prevent the infestation of this pest. Boric acid was used as the treatment to determine the toxicity trials on $H$. aequalis. Boric acid is a common type of preservative or pesticide applied to controls insects infestation, spiders, algae and fungi (Environmental Protection Agency, 1993). The boric acid is white solid, odourless and inert at room temperature and usage in food, beverages and non-food products. Furthermore, boric acid are found toxic to insects when it ingest and also very abrasive especially towards the exoskeleton of the insects (Environmental Protection Agency, 1993). In addition, boric acid is a common water-borne preservative use to treat heveawood; although, no studies carried out to determine the sufficient dose of boric acid needed to control the $H$. aequalis infestation on heveawood. Aydin and Colakoglu (2007) studied that borates compound are likely to be used more to treat solid and engineered wood for indoor purposes. Therefore, the present study conducted aims to establish a suitable method for preservative trials on the wood borer and access the toxicity levels of boric acid for controlling the $H$. aequalis infestation.

\section{MATERIALS AND METHODS}

The toxicity trials of boric acid, adult's beetles were collected from infested heveawood and Dyera costulata wood obtained from Wood Composite Laboratory, Faculty of Forestry. Purposes of using beetles collected from infested wood source were to obtain voracious freshly emerged adults to obtain accurate result of toxicity trials test. The lateral view of male and female adults is shown in Fig. 1 and Fig. 2, respectively. The adults of $H$. aequalis were kept in Petri dish lined with black filter paper and covered for one night without any nourishment to achieve successful mating among them. After that, the mated male and female were exposed to cassava blocks and maintained for 8 weeks until the emergence of the F1 phenotypes generation. 


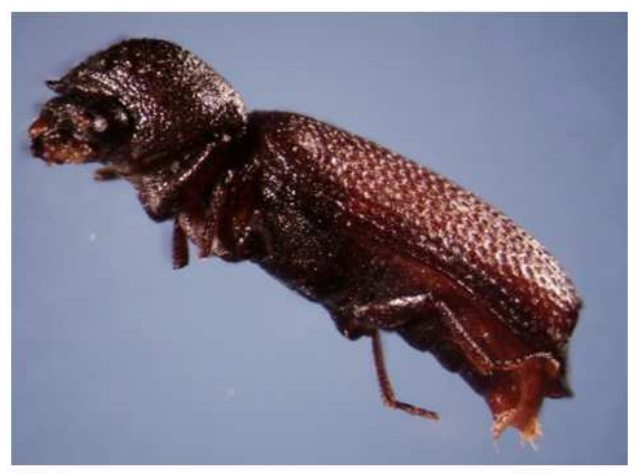

Fig. 1: Lateral view of male adult (magnification: $\times 1.26$ )

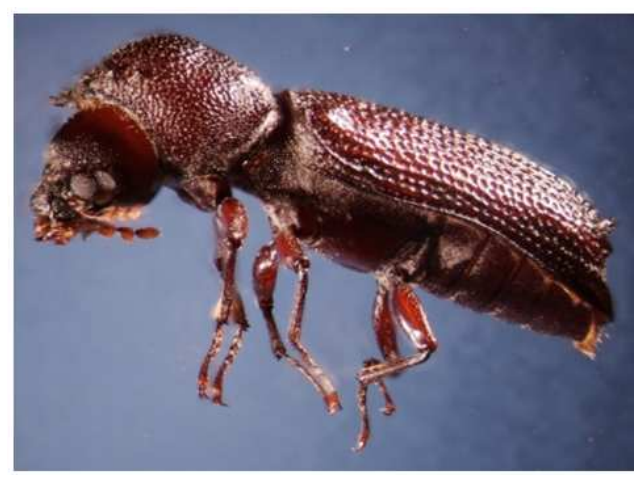

Fig. 2: Lateral view of female adult (magnification: $\times 1.26$ )

The cassava block was chosen as the test blocks instead of heveawood because it gives faster results. Hodges et al. (1985) reported that Bostrychidae is an important pest that infests cassava chips in tropical area in Africa. Furthermore, Dinoderus spp. and P. truncates also found to be infesting farm stored products in Ghana (Rees, 1991). The size of cassava blocks stated by Abood et al. (1994) was modified slightly to form test blocks. The sizes of test block used are $(2.0 \times 5.0 \times 1.5) \mathrm{cm}^{3}$ and was used as the basis for the assessment of boric acid toxicity trials. The cassava blocks were dried in the oven at $60^{\circ} \mathrm{C}$ for $48 \mathrm{~h}$. This must be done continuously in order to obtain a $12 \%$ moisture content of cassava. In order to avoid water vapour been trapped in the plastic bag filled with the oven dried cassava blocks, the dried cassava block was air dried before kept in plastic bag.

Preparation of boric acid: Boric acid is used as the treatment in order to establish the exact dose of boric acid concentration to preserve the heveawood. In the laboratory, method of study of the effects of boric acid equivalent on termite, boric acid equivalent used was in the range of 1.1-1.2\%. Hence, for toxicity trials of boric acid on $H$. aequalis, five different level of boric acid ranging from $1-5 \%$ were used. The calculations of boric acid concentration are as follows:

Volume, $\mathrm{V}=1000 \mathrm{~mL}$

Weight of Boric acid powder, $\mathrm{g}=\mathrm{X}$

$(\mathrm{X} / \mathrm{V}) \times 100 \%=$ Boric acid concentration percentage $(\%)$

Akhter (2005) found that heveawood can be treated satisfactorily by soaking and pressure process with acceptable penetration and retention. Hence, soaking method was used to preserve the cassava test blocks with 5 different concentrations which were 1-5 respectively. Dhamodaran and Bhat (1992) mentioned that net average of $0.4 \%$ borax-boric acid is adequate to give protection against fungi and borers of wood species. Moreover, in the study of efficacy of boraxboric acid preservatives on heveawood, Borax-Boric Acid and Sodium-Pentachlorophenate (NaPCP) mixture of the treatment by dipping in mixture of required concentration for a specific time given by the equation (Narayanan et al., 2005):

$$
\mathrm{T}=3.2(\mathrm{D} / \mathrm{C})^{2}
$$

Where:

$\mathrm{D}=$ Thickness of the specimen, $\mathrm{cm}$

$\mathrm{T}=$ Immersion time, $\mathrm{h}$

$\mathrm{C}=$ Concentration of the solution in percentage

The thickness of cassava test block, $\mathrm{D}=1.5 \mathrm{~cm}$

Exposing treated test blocks to $\boldsymbol{H}$. aequalis adults: The voracious $H$. aequalis culture in heveawood medium was used. Two pairs of $H$. aequalis adults with equal female and male were exposed to the test blocks. The mortality, number of holes formed, duration of frass discharge and the behaviour were observed through this experiment on five different concentrations of treated test blocks. This observation was done daily for two weeks. The data were analysed to evaluate the mean mortality of $H$. aequalis adults, mean number of holes, duration of frass discharge and mean weight loss of boric acid treated test blocks and suitable boric acid concentration to control $H$. aequalis attacks. The calculation of the data used to determine the significance level and mean differences by using Analysis of Variance (ANOVA). The Tukey's (HSD) were used to detect any significant differences between 
Am. J. Agri. \& Biol. Sci., 6 (1): 84-91, 2011

mean values among treatments. The Statistical Analysis System (SAS Ver. 9.2) was used for the statistical analysis.

\section{RESULTS}

Table 1 shows the mean mortality of $H$. aequalis adults on boric acid treated test blocks over 14 days. The numbers of dead adults obtained from the treated test block with $1-5 \%$ concentration within two weeks were higher compared to the control test. Also according to the result, $1-2 \%$ boric acid is enough to kill $H$. aequalis adults due to the preservative action as a stomach poison when the insects digest it. Mean mortality of adults on control test block was $0.6 \pm 0.40$ while mean mortality of adults on 1 and $2 \%$ boric acid treated test blocks were $3.6 \pm 0.25$ and $3.0 \pm 0.32$. Moreover, mean mortality of adults on 3, 4 and 5\% boric acid treated test blocks were $4.0 \pm 0.00,4.0 \pm$ 0.00 and $3.8 \pm 0.20$, respectively.

Table 2 shows the mean number of holes made by H. aequalis adults on boric acid treated test blocks with different concentrations. Furthermore, 0\% boric acid concentration test block showed the highest number of holes followed by $1-4 \%$ boric acid concentration treated test blocks. The mean number of holes made by $H$. aequalis adults on $0 \%$ boric acid treated test block was $8.4 \pm 0.98$. The mean number of holes on $1 \%$ and $2 \%$ boric acid treated test blocks were $1.4 \pm 0.25$ and $1.0 \pm$ 0.45 , while the 3,4 and $5 \%$ boric acid treated test blocks were $0.6 \pm 0.40,0.2 \pm 0.20$ and $0.0 \pm 0.00$. From the observation, there were no holes made by $H$. aequalis adults on the test block which were treated with 5\% boric acid, indicating a sufficient amount to control the infestation of this wood borer on heaveawood.

Table 3 shows the mean duration of frass discharge by the $H$. aequalis adults on boric acid treated test blocks. The duration of frass discharge were higher on $0 \%$ boric acid treated test block with a mean value of $60.0 \pm 1.64$ followed by $1-5 \%$ with $9.6 \pm 1.60,6.6 \pm$ $1.66,4.4 \pm 1.17,3.0 \pm 0.00$ and $0.0 \pm 0.00$, respectively.

Table 4 shows the mean weight loss of boric acid treated test blocks. The mean weight loss of control test block showed the highest value of $2.25 \pm 0.45$ at $0 \%$ concentration while the 5\% treated test block had no weight loss recorded. This result could be due to the absence of boring activities done by $\mathrm{H}$. aequalis on 5\% boric acid treated test blocks. The mean weight loss for 1 and 2 boric acid treated test blocks are $1.81 \pm 0.10$ and $0.54 \pm 0.21$, while for 3 and $4 \%$ boric acid treated test blocks are $0.60 \pm 0.09$ and $0.44 \pm 0.04$.
Table 1: The mean mortality of $H$. aequalis adults over 14 days

\begin{tabular}{ll}
\hline Boric acid conc. $(\%)$ & Mortality $(\%)$ \\
\hline 0 & $15 \pm 0.40 \mathrm{c}$ \\
1 & $90 \pm 0.25 \mathrm{ab}$ \\
2 & $75 \pm 0.32 \mathrm{~b}$ \\
3 & $100 \pm 0.00 \mathrm{a}$ \\
4 & $100 \pm 0.00 \mathrm{a}$ \\
5 & $95 \pm 0.20 \mathrm{a}$ \\
\hline
\end{tabular}

Means followed by the same letter are not significantly different at $\mathrm{P} \leq 0.05$ as determined by Tukey`s HSD test.

Table 2: The mean number of holes made by $H$. aequalis adults over 14 days

\begin{tabular}{ll}
\hline Boric acid conc. (\%) & Number of holes $(\%)$ \\
\hline 0 & $8.4 \pm 0.98 \mathrm{a}$ \\
1 & $1.4 \pm 1.25 \mathrm{~b}$ \\
2 & $1.0 \pm 0.45 \mathrm{~b}$ \\
3 & $0.6 \pm 0.40 \mathrm{bc}$ \\
4 & $0.2 \pm 0.20 \mathrm{bc}$ \\
5 & $0.0 \pm 0.00 \mathrm{c}$ \\
\hline
\end{tabular}

Means followed by the same letter are not significantly different at $\mathrm{P} \leq 0.05$ as determined by Tukey`s HSD test.

Table 3: The mean duration of frass discharge by $H$. aequalis adults over 14 days

\begin{tabular}{ll}
\hline Boric acid conc. (\%) & Duration \\
\hline 0 & $60.0 \pm 1.64 \mathrm{a}$ \\
1 & $9.6 \pm 1.60 \mathrm{~b}$ \\
2 & $6.6 \pm 1.66 \mathrm{~b}$ \\
3 & $4.4 \pm 1.17 \mathrm{bc}$ \\
4 & $3.0 \pm 0.00 \mathrm{bc}$ \\
5 & $0.0 \pm 0.00 \mathrm{c}$ \\
\hline
\end{tabular}

Means followed by the same letter are not significantly different at $\mathrm{P} \leq 0.05$ as determined by Tukey`s HSD test.

Table 4: Mean weight loss of boric acid treated test blocks

\begin{tabular}{ll}
\hline Boric acid conc. (\%) & Weight loss $(\mathrm{g})$ \\
\hline 0 & $2.20 \pm 0.45 \mathrm{a}$ \\
1 & $1.81 \pm 0.10 \mathrm{a}$ \\
2 & $0.54 \pm 0.21 \mathrm{~b}$ \\
3 & $0.60 \pm 0.09 \mathrm{~b}$ \\
4 & $0.44 \pm 0.04 \mathrm{~b}$ \\
5 & $0.0 \pm 0.00 \mathrm{c}$ \\
\hline Means followed by the same letter are not significantly different at
\end{tabular}
$\mathrm{P} \leq 0.05$ as determined by Tukey`s HSD test.

\section{DISCUSSION}

The cassava pellets were found to be very suitable for collecting $H$. aequalis larvae instar by first, second, third, fourth, fifth and sixth instar. Moreover, $H$. aequalis eggs also can be obtained easily by using cassava pellet without any physical injuries to the beetle's egg. This particular technique described by Abood et al. (1994) as a standard technique with great potential for retrieval of eggs and different stages of larvae instars.

The method of collecting a newly emerged voracious $H$. aequalis adults are by keeping a number of vigorous $H$. aequalis adults collected directly from 
infested heveawood for $24 \mathrm{~h}$ without any nourishment. This is to allow successful mating among the female and the male adults. After that, $H$. aequalis adults were exposed to a new cassava block and maintained for about two months respectively. Then, the newly emerged adults were used for the preservative trials test.

The results showed that the $H$. aequalis adults can also be collected or forced out from the infested wood by wrapping the wood with a thin and transparent layer of cling film for $24 \mathrm{~h}$. Through this method, the $H$. aequalis adults tended to penetrate out from the holes through the cling film. These techniques were able to determine the present of insects on a particular infested wood. Hazarika et al. (2005) described that the female of Bostrychidae tends to insert their eggs in host plant tissues which protect it offspring from danger and extreme conditions. In addition, the adult larvae and eggs in the wood will not be harmed or killed upon the wood has been cut. Moreover, we can keep the infested wood for longer periods instead of cutting the wood into slices that may kill the $H$. aequalis. Similarly, Abood (2008) proved that infestation of $H$. aequalis will keep on going until the entire inside structure of the wood become smooth and eventually leaving a fine powdery frass.

There are several prominent differences observed throughout the research about $H$. aequalis that was collected directly from infested heveawood. The larvae of $H$. aequalis collected from infested heveawood are yellowish brown in colour compared to culture of $H$. aequalis which are yellowish white in colour. Moreover, larvae collected from infested heveawood also have a visible black line on its back which could not be found on culture larvae. The black line formed was due to the fact that the larvae has been consuming lignin from the heveawood while a laboratory culture larva does not get any lignin supply in cassava. In addition, Cymorek (1968) clarified that wood-boring insects were forced to ingest the wood because this particular pest due to unable to digest cellulose as a source of carbohydrate.

In addition, when the voracious $H$. aequalis adults from infested heveawood were exposed to new culture medium or cassava block, the insects will actively move around the blocks. On the other hand, when a cultured of $H$. aequalis adults with an artificial diet were transferred to the new cassava block for starting new culture, however, some of it does not bore or become inactive due to the new environment exposure. Furthermore, a number of the culture adults died when exposed to new cassava due to the weakness of $H$. aequalis could not penetrate or bore through the hard cassava block wall. However, this situation was not observed on cassava blocks that had been exposed to the voracious adults. After a few hours of exposure, there were of frass discharge indicating that the insects are trying to bore the cassava blocks (Woodruff and Fasulo, 2006).

The aggression among the female and male of voracious $H$. aequalis adults was observed when kept in a petri dish lined with filter paper for $24 \mathrm{~h}$ without any nourishment. This was done to achieve successful mating among them and fertilise female adults before being cultured. The activeness and aggressive behaviour among the voracious $H$. aequalis adults had caused many of its members to lose its limb concomitantly died. On the other hand, there was a difference in behaviour observed on group of $H$. aequalis collected from the maintained culture of artificial diet in the laboratory. Slow movement and less interaction among adults indicated that a successful mating would not be achieved if the cultured of $H$. aequalis was used for preservative trials.

On the first day of exposure to the $1 \%$ boric acid treated test block, all the $H$. aequalis adults were actively moving around the blocks and leaving gnawing marks. Moreover, there was frass discharge noticed on the treated heveawood indicating that the adults bore into the blocks. Furthermore, some of the adults tend to be in a crack on the test blocks even though the blocks were impregnated with boric acid. However, after one day of exposure to the treated test blocks, some of the adults started moving away from the blocks. After the second day of exposure, some of $H$. aequalis still bore, but most of it had become weak and sluggish. This symptom indicates that the boric acid ingested by $H$. aequalis was acting as a stomach poison. The first mortality of $H$. aequalis was noticed on the second day of exposure. In addition, a number of holes made by $H$. aequalis were recorded on all of the five replicates of $1 \%$ boric acid treated test blocks on the very first day of exposure.

Earliest frass discharge noticed was on the first day of exposure but there were less number of holes made by $H$. aequalis compared to the number of holes in $1 \%$ boric acid treated test block. The mortality of $H$. aequalis was also higher on $2 \%$ boric acid as compared to $1 \%$ boric acid treated test blocks. Furthermore, the mortality duration rate was faster than the mortality duration rate of $1 \%$ boric acid treated test block where the first mortality of $H$. aequalis recorded on the first day of exposure. The mortality of the first day was observed on the second and third replicate while fewer holes were found on the third, fourth and fifth replicate. Moreover, the behaviour of $H$. aequalis in 
terms of activeness was becoming less strong and also being unable to climb or to grip on the treated test block.

The $3 \%$ boric acid treated test blocks exhibited the earliest mortality was on the first replicate in the first day of exposure. Two mortalities of $H$. aequalis were recorded during the first day. Furthermore, the earliest holes made by $H$. aequalis were recorded on the fourth replicate with only one hole. Total of three holes were made on the $3 \%$ boric acid treated test blocks. On the other hand, no holes were made on the first, second and the fifth replicate. Some of the adults liked to hide in the cracks of the test blocks. This situation may be due to the tendency of $H$. aequalis to bore the softer inner part of the crack compared to the harder outer part of the block. At the 10 day of exposure, all adults on the first and third replicates were dead. The exoskeleton colour of the adults also became darker and drier due the contact of boric acid being very abrasive on the H. aequalis exoskeleton.

The $4 \%$ boric acid treated test block, only one hole was made which was noticed on the third replicate test block. The earliest mortality was recorded on the first day, in the fourth and fifth replicate, respectively. In addition, all the adults on the second replicate died on the ninth day of exposure. Furthermore, no visible holes were noticed on first, second, fourth and fifth replicates. At the beginning of exposure, the $H$. aequalis adults were actively moving around the treated test blocks. Then, $H$. aequalis started showing abnormal behaviour such as suddenly became hyperactive, before slowing down and then stop moving completely. The hyperactive behaviour movement showed that the boric acid act as a stomach poison when it ingested. The ingestion of the poison starch by $H$. aequalis can be detected by the presence of gnawing marks on the treated test blocks.

The mortality duration at 5\% boric acid treated test block was slower compared to the mortality duration rate recorded at $2 \%$ boric acid treated test block. The earliest mortality was observed on the second day of exposure. The second replicates had the earliest complete mortality of $H$. aequalis by the eighth day of exposure. From the study, the mortality duration was relatively slow in each replicate. In the first replicate, after the first mortality, the next mortality only happened on the sixth and twelfth days of exposure. On the second replicate, earliest mortality was observed on the sixth day with two mortalities of $H$. aequalis. Most of the adults on $5 \%$ boric acid treated test block could not actively move around the test blocks during the first day of exposure. Moreover, there was no sign of frass discharge and holes.
From the observation done on the preservative trials of the wood borer of $H$. aequalis, the 5\% boric acid concentration was found to be adequate to prevent attack of $H$. aequalis because there were no infestations noticed on each replicate. In addition, Abood (2008) recommended that dipping treatment is suitable to be implemented for logs at logging area or factory in order to preserve the wood for long-term use. Moreover, there was no frass discharge seen on the test block. Furthermore, no gnawing marks had been done by $H$. aequalis, hence none were detected on the cassava test block surface.

\section{CONCLUSION}

The presence of $H$. aequalis adults in infested wood can be detected by the existence of hole made by the insects through a thin layer of cling film that was used to wrap the infested wood. In addition, there were differences in physical and behavioural observed between $H$. aequalis cultured in rich starch diet with the one collected from infested wood. Furthermore, freshly emerged $H$. aequalis adults have been found to be more suitable to be used as indicator to examine the boric acid toxicity trials compared to the larvae because the adults of $H$. aequalis gave visible and earlier notification of mortality, number of holes made and discharge of frass on test blocks. The 5\% boric acid concentration was found to be sufficient to control the activeness of $H$. aequalis due to no holes and frass discharge here detected on test blocks treated with that particular concentration. There is a necessity to study the relationship between the $H$. aequalis and its food sources especially wood along with population growth of $H$. aequalis larvae and adults on different hosts. Through such a study, the effects on $H$. aequalis can be discovered if certain substrates are removed from the host. Moreover, the predisposing factors affecting infestation by $H$. aequalis on the hosts can be established. Moreover, study of toxicity trials of boric acid on $H$. aequalis by using heveawood and other potential hosts of $H$. aequalis should be established.

\section{REFERENCES}

Abood, F., R. Murphy and R. Berry, 1994. New perspective on the biology of the tropical powderpost beetle, Minthea rugicollis Walk. International Group on Wood Preservation. http://myais.fsktm.um.edu.my/cgi/paracite

Abood, F., 2008. Degradation on wood by insects and the effects on furniture production. The Malayan Forester, 71: 95-105. ISSN: 03022935 
Akbar, M.H., A.S. Jamaluddin, N.M. Nik Ab. Majid, H. Abdul-Hamid, S. Jusop, A. Hassan. K.H. Yusof and A. Abdu, 2010. Differences in soil physical and chemical properties of rehabilitated and secondary forests. Am. J. Applied. Sci., 7: 12001209. http://www.scipub.org/fulltext/ajas/ajas791200120 9.pdf

Akhter, K., 2005. Preservative treatment of Rubber Wood (Hevea brasiliensis) to increase its service life. Proceeding of the International Research Group on Wood Protection, 36th Annual meeting, Banglore (India), pp: 24-28. http://irgwp.com/documents/2005/lateandcorrected /IRG\%2005_40320.pdf

Aydin, I. and G. Colakoglu, 2007. Variation in surface roughness, wettability and some plywood properties after preservative treatment with boron compounds. Buil. Environ., 42: 3837-3840. DOI: 10.1016/j.buildenv.2006.11.009

Creffield, J.W., 1996. Wood Destroying Insects-Wood Borers and Termites. 2nd Edn., CSIRO Division of Forestry and Forest Products. pp: 44. www.earthlife.net/insects/pub/CSIRO.html

Creffield, J.W., 1991. Wood Destroying Insects, Wood Borers and Termites. CFIRO Publications, East Melbourne, Australia, pp: 44. http://www.fwpa.com.au/Resources/RD/Reports/P N/03.1313.pdf? $c=z \& p n=P N 03.1313$

Cymorek, S., 1968. Adaptations in wood-boring insects: examples of morphological, anatomical, physiological and behavioural features. Rec. Annu. Convent. $\quad$ B.W.P.A., 18: 161-170. http://80.153.81.79/ ento/lit01/cymorek1968e.pdf

Dhamodaran, T.K. and K.M. Bhat, 1992. Diffusion Treatments of Rattans. In: Rattan Management and Utilization, Basha, S.C. and Bhat, K.M. (eds.). KFRI Publication, Kerala India, pp: 294-298. http://www.irgwp.com/documents/2005/lateandcor rected/IRG_05-43020.pdf

De Angelis, J., 1995. Preventing and Controlling Powderpost Beetles. In: And Around the Home, Oregon State University, Pacific Northwest Publication, Corallis. http://www.extension.oregonstate.edu/katalog/pdf/ pnw/pnw326.pdf

Hazarika, L.K., M. Deka and M. Bhuyan, 2005. Oviposition behaviour of the rice hispa Dicladispa armigera (Coleoptera: Chrysomelidae). Int. J. Trop. Insect Sci., 25: 50-54. DOI: 10.1079/IJT200553

Hodges, R.J., J. Meikand and H. Denton, 1985. Infestation of dried cassava (Manihot esculenta Crantz) by Prostephanus truncates Horn (Coleoptera: Bostrichidae). J. Stored Prod. Res., 21: 73-77. DOI: 10.1016/0022-474X(85)90024-4
Environmental Protection Agency., 1993. Reregisteration eligibility decision document: Boric Acid and its Sodium Salsts; EPA 738-R-93017; US, Environmental Protection Agency, Office of Pesticide Programs, U.S Government Printing Office, Washington DC. http://npic.orst.edu/factsheets/borictech.pdf

Holscher, K. and W. Wintersteen, 1998. Fumigation Iowa Commercial Pesticide Applicator. Iowa State University Press, Iowa.http://www.extension.iastate.edu/Publications /CS27.pdf

Ho, H.F. and W.S. Hashim, 1993. Heterobostrychus aequalis-A Common Powderpost Beetle or Timbers. FRIM Technical Information No. 44. Forest Research Institute of Malaysia, Kepong. http://info.frim.gov.my/cfdocs/infocenter/Korporat/ 2003Publications/Links/FTI/FTI44.htm

Ivie, M.A., 2002. Bostrichidae Latreille 1802. In Arnett RHJr, Thomas, M.C., Skelley, P.E.and Frank, J.S. (Eds). American Beetles,CRC Press, Boca Raton, 233-244 pp.www.pensoftline.net/zookeys zookyes, 26: 33-51. DOI: 10.3897/zookeys.26.88

Khalsa, H.G., B.S. Nigam and P.N. Agarwal, 1965. Resistance of Coniferous timbers to Lyctus attack. Indian J. Entomol. 33: 377-388. http://www/forestry.org.au/pdfmembers/afj/AFJ_Ju nes_2002_65-2/07Peters.pdf

Leng, L.Y., O.H. Ahmed, N.M.A. Majid and M.B. Jalloh, 2009. Organic matter, carbon and humic acids in rehabilitated and secondary forest soils. Am. J. Applied Sci., 6: 824-8. $\quad$ DOI: 10.3844/ajassp.2009.824.828

Narayanan, S., U. Baskarand and K.P. Jaya, 2005. Strength and durability of treated rubberwood. J. Insti. $\quad$ Eng. $\quad 86: \quad 1-6$. http://www.ieindia.org/pdf/86/vc86m5521.pdf

Peters, B.C., J.W. Creffield and R.H. Eldrige, 2002. Lyctine (Coleoptera: Bostrychidae) pest of timber in Australia: A literature review and susceptibility testing protocol. Australia For., 65; 107-119. http://www.fwpa.com.au/Resources/RD/Reports/P N03.1313.pdf?c=z\&pn=PN03.1313

Rees, D.P., 1991. The effect of Teretriosoma nigrescens Lewis (Coleoptera: Histeridae) on three species of storage Bostrichidae infested shelled maize. J. Stored Prod. Res., 27: 83-86. DOI: 10.1016/0022474X(91)90036-C

Saga, B.T., O.H. Ahmed, A.S. Jamaluddin, H. Abdul-Hamid, S. Jusop, N.M. Nik Ab. Majid, A. Hassan, K.H. Yusof and A. Abdu, 2010. Selected soil morphological, mineralogical and sesquioxides properties of rehabilitated and secondary forests. Am. J. Environ. Sci., 6: 389-394. ISSN: 1553$345 \mathrm{X}$ 
Satrio, A.E., S. Gandaseca, O.H. Ahmed and N.M.A. Majid, 2009. Influence of chemical properties on soil carbon storage of a tropical peat swamp forest. Am. J. Applied Sci., 6: 1970-1973. DOI: 10.3844/ajassp.2009.1970.1973

Wong, A.H.H., Y.S. Kim, A.P. Singh and W.C. Ling, 2005. Natural durability of tropical species with emphasis on Malaysian hardwoods-variations and prospects. Proceeding of the International Research Group on Wood preservation, the 36th annual Meeting, Apr. 24-28, Bangalore, India, pp: 33-51. DOI: $10.3897 /$ zookeys.26.88
Woddruff, R.E. and T.R. Fasulo, 2006. An oriental wood borer, Heterobostrychus aequalis Waterhouse (Insecta: Coleoptera: Bostrichidae). IFAS Extension, 58: 1-4. http://edis.ifas.ufl.edu

Woodruff, R.E, 1967. An oriental wood borer, Heterobostrychus aequalis Waterhouse, recently established in Florida. Entomol. Circ., 58: 1-2. http://www.doacs.state.fl.us/pj/enpp/ento/entcirc/en to58.pdf 